Article

\title{
Rural Renewal of China in the Context of Rural-Urban Integration: Governance Fit and Performance Differences
}

\author{
Rongyu Wang and Rong Tan * \\ Department of Land Management, Zhejiang University, Yuhangtang Road, 866, Hangzhou 310058, China; \\ wangrongyu@zju.edu.cn \\ * Correspondence: tanrong@zju.edu.cn
}

Received: 10 January 2018; Accepted: 29 January 2018; Published: 2 February 2018

\begin{abstract}
In recent years, rural-urban integrated development has become a vital national strategy in China. In this context, many regions have implemented rural renewal projects to enhance the vitality and development of rural areas. The objective of this study is to reveal the reasons why different rural renewal modes have emerged in contemporary China and assess their ability to facilitate rural-urban integration. An analytical framework, the Institution of Sustainability (IoS) and a comparative analysis of two cases are used for the rural renewal evaluation. Our findings indicate that the properties of transactions and the characteristics of the actors involved jointly determine the governance structures of rural renewal. Furthermore, different governance structures contribute to performance differences, particularly differences in the physical outcomes, distribution effects and process efficiency. Finally, we suggest relevant policy recommendations.
\end{abstract}

Keywords: rural renewal; rural-urban integration; institutional analysis; governance structure; China

\section{Introduction}

China has experienced rapid economic development for over 30 years, which has accelerated the improvement of rural and urban areas. However, these improvements are imbalanced. A significant gap is observed between rural and urban areas in their physical conditions, such as their living conditions and residential environments. In rural areas, the land use structure for production, living and ecology is not sufficiently rational and the land use pattern is far too extensive. And the rural residential environment is obsolete, badly planned and poor [1]. Moreover, the social wealth gap between rural and urban areas is still large. In 2011, the income gap between urban and rural areas was 3.13:1 [2]. Therefore, the Chinese government put forward the national policy so called "Rural-urban integrated development" to bridge the development gaps between rural and urban areas [3-6]. In particular, living quality of rural areas should be improved to realize the equity on physical conditions in rural-urban areas; and income and vitality of rural areas should be increased and enhanced respectively to narrow the social wealth gap in rural-urban areas. To facilitate rural-urban integrated development, the Chinese government has promoted a strategy of rural renewal to construct a new countryside with the characteristics of developed production, affluent living conditions, civilized local customs, a clean and tidy village appearance and democratic administration [3-6]. Recently, the Chinese government further announced to accelerate rural revitalization [7]. At present, rural renewal has been implemented nationwide for many years.

In fact, rural renewal is not a phenomenon unique to China. The Rural Development Policy (2014-2020) of the European Union proposed improvements to resource efficiency and the viability and competitiveness of all types of agriculture; improvements to the ecosystems related to agriculture and forestry; improvements to the social inclusion, poverty reduction and economic development [8]. 
However, this paper focuses on rural renewal as it pertains to activities related to consolidating land, improving living conditions and boosting the economy to promote new countryside construction and rural revitalization in the Chinese context of rural-urban integration.

In general, two modes of rural renewal have primarily been observed in contemporary China. The first mode is government-led rural renewal. As the investor and organizer, the government is actively involved in the entire process of rural renewal. For instance, local governments can manipulate redevelopment of villages within the city, namely, urban village renewal [9], or finance and enforce hollowed village revitalization and land consolidation projects to optimize the rural land use structure and residential environment to meet the requirements from the central government $[10,11]$. The second mode is self-organized rural renewal. Led by the village committee and elites, farmers organize themselves to implement rural renewal and boost rural development by taking advantage of the local natural, economic and social resources. For example, many villages in the Pearl River Delta region have experienced industrialization and urbanization launched by village collectives and village leaders [12]. In addition, without government intervention, farmers in certain regions still drive rural land consolidation and rural construction land transfers to promote village development $[13,14]$.

Rural renewal in China has already attracted the attention of many researchers and a substantial body of literature is concentrated on urban village renewal. The literature explains the power relations and urban coalitions among stakeholders as well as the distribution of incremental land revenue during urban village renewal $[15,16]$. In addition, the literature analyzes the multiple effects urban village renewal has exerted on urban development, such as ameliorating the physical environment of the city and improving living conditions but failing to completely eliminate the phenomenon of urban villages [17,18]. And studies have also focused on the more general object of villages located at the urban fringe and in remote areas of China. The literature discusses the diverse functions of hollowed village revitalization and land consolidation, such as promoting agricultural production, upgrading living conditions in rural areas and protecting the environment $[19,20]$ and a comprehensive index system has been established to evaluate the performances of new countryside construction in several regions of China as a reflection of performance diversity [21].

However, to the best of our knowledge, few studies have explored the reasons underlying the occurrence of different rural renewal modes. Moreover, although studies have focused on the performance of rural renewal, the performance was not assessed from the perspective of rural-urban integration or at the level of governance structure (i.e., rural renewal modes). Hence, our research intends to answer the following questions. First, why have different modes of rural renewal emerged in China? Second, what are the performance differences of the rural renewal modes in the context of rural-urban integration? Evidently, conducting this type of research is of great importance for optimizing rural renewal governance to optimize its key role in fulfilling rural-urban integration in contemporary China. To that end, we will study rural renewal in China through two typical cases based on an Institution of Sustainability (IoS) framework.

More specifically, we attempt to identify the determinants of selection between government-led and self-organized modes to reveal the logic of governance fit. However, we also wish to elucidate the performance of government-led and self-organized rural renewal from the perspectives of physical outcomes, distribution effects and process efficiency. In other words, we mainly concentrate on the directly observed land use change and socio-economic performance of rural renewal. However, the indirect or hidden outcomes, such as ecological issues generated by rural renewal, external actors influenced by rural renewal and other mechanisms interconnected with rural renewal, are not considered because these processes and outcomes occur gradually and are too complicated to identify [22,23], particularly for a single paper with a finite scale and limited evidence.

The paper is organized as follows. The second section modifies the IoS framework and applies it to understanding rural renewal in China, namely, analyzing the governance fit and performance differences in theory. The third section introduces the research methodology, including the methods for case selection, survey and comparison analysis. The fourth section displays the main process 
and outcomes of rural renewal in China through two typical cases. The fifth section presents the comparative analysis between the two cases based on the theoretical framework. The last section provides our conclusions and recommendations.

\section{Understanding Rural Renewal: Perspective of the IoS Framework}

The IoS framework was created to resolve issues related to the social-ecological system (SES), particularly issues related to institutional analyses and performance assessments of natural resource management [22]. The IoS framework consists of an action arena and four exogenous elements: transactions, actors, institutions and governance structures. Rural renewal is a systematic process that leads to natural and social relation conversions and involves various elements, such as land resources, humans, land-related institutions and governance structures. We can further decompose and understand the systematic structure for which rural renewal is the core by including rural land resources in the framework (Figure 1).

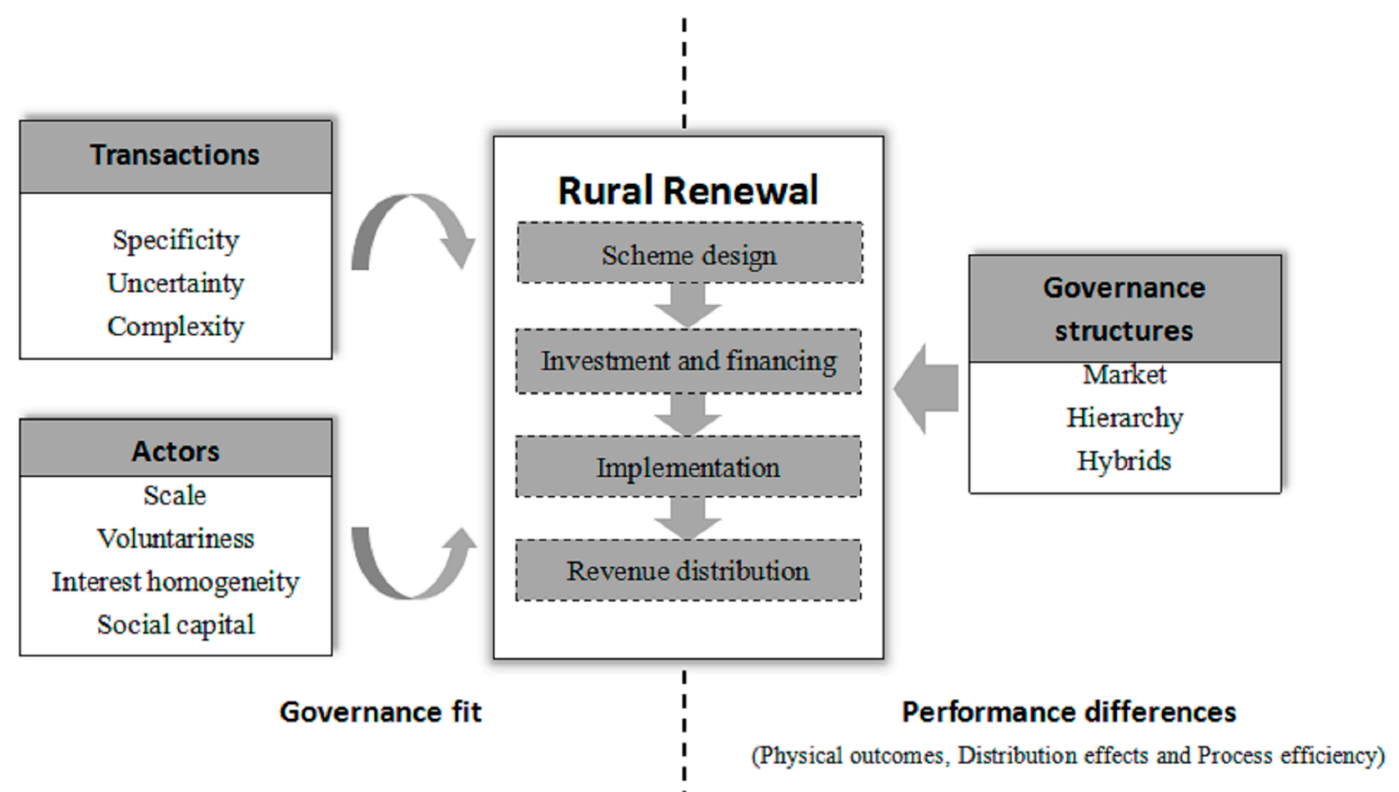

Figure 1. IoS analysis of rural renewal.

\subsection{IoS Framework for Rural Renewal}

In general, an IoS analysis focuses on methods of regularizing human actions that lead to transactions that affect the relationship between natural and social systems [22] and it attempts to transfer Williamson's discriminating alignment, i.e., conventional TCE (transaction costs economics) to the analysis of resource and environment governance of social-ecological interdependence. In Williamson's TCE paradigm, the units of analysis are transactions, namely, the exchange of goods and services, which are subject to the linear technical processes of industrial production [23]. For Williamson (1985), a transaction occurs when a good or service is transferred across a technologically separable interface. One stage of activity terminates and another begins [24].

However, the IoS framework recognizes nature-related transactions as its key feature. Nature-related transactions are defined as interrelated changes in the utility of actors mediated by non-human biophysical systems, which are subject to intentional action (agency) by at least one actor [23]. Such transactions include transfers with the following features: they may be indirect, have a spatial dimension, involve time lags, may be complicated to reproduce and may be hidden [22]. In addition, the IoS framework also considers the transaction initiators, i.e., human actors $[22,25]$. According to the above pattern, the complicated social-ecological interdependence 
can be well elaborated. Furthermore, the social construction of institutions and governance structures is dependent on the properties of the transactions and the characteristics of the actors involved [22].

Rural renewal triggers land use change and social relation reconstruction and these alterations mutually produce the intended or unintended, targeted or non-targeted, predictable or unpredictable interconnections within the social-ecological systems. For example, rural land consolidation may lead to positive and negative variations in soil, water and plants. Improvements in the physical conditions of one village may have neighborhood effects on other villages and the rural industry transformation (e.g., from agricultural to non-agricultural domination) may even exert spill-over impacts on the entire region in a cumulative manner. All interconnections show the apparent nature-related attributes of rural renewal. In brief, one economic actor's choice to conduct a nature-related transaction may induce many other linked transactions and produce diverse effects that affect numerous other actors over spatial and temporal distances and via complex biophysical mechanisms [26]. Obviously, the case of rural renewal is not an exception. Admittedly, the IAD (Institutional Analysis and Development) framework or the SES (Social-ecological Systems) framework may also be employed for analyzing rural renewal $[27,28]$. Compare with the above two frameworks, the components of the IoS framework are more manageable, neither too specific nor too abstract to illuminate the governance fit and performance differences of rural renewal within a single paper. Furthermore, the IoS framework covers the core components of the above two frameworks. In summary, the IoS framework is a more suitable choice.

However, the limited spatio-temporal research scale and available empirical evidence become the challenges for us to conduct a "complete" IoS analysis. Therefore, the IoS analysis on rural renewal in this paper still follows Williamson's TCE paradigm and it partially (rather than fully) considers the nature-related aspect. More specifically, we concentrate only on the direct land use changes and linear socio-economic outcomes induced by rural renewal and integrate certain properties of the nature-related transactions (i.e., complexity; see Section 2.2.2) and characteristics of the actors (see Section 2.2.2) into Williamson's discriminating alignment to interpret the governance fit and performance differences while ignoring certain externalities and interconnections associated with rural renewal.

Moreover, according to the research questions of this paper, we intend to analyze a situation at the governance level under the assumption that the institutional rules are temporarily fixed [27]. In general, the institutions for rural renewal in China are nearly equivalent across the country, particularly in terms of land property rights, land laws and land administration systems. Hence, we modify the IoS framework to recognize the institutions as a constant rather than a variable (Figure 1).

\subsection{Applying the Framework}

\subsubsection{Center of the Framework: Action Arena}

The action arena is the center of the framework. Within the social-ecological system, the physical world and the social world interact with each other in the action arena [22]. The process and direct outcomes of rural renewal that can be observed in reality reflect the interactions among elements in the social-ecological systems. Thus, we regard rural renewal as an action arena. Furthermore, rural renewal entails four stages: scheme design, investment and financing, implementation and revenue distribution. These four stages compose the different action situations in the action arena.

1. Scheme design. This stage is the first and one of the most important steps of rural renewal because the guidelines and general plan for rural renewal, such as the targets, scale, routes and arrangements, are determined and decided in this stage. If the scheme is not sufficiently rational or does not consider economic, social and ecological relations and subsequently causes certain disputes, then the rural renewal will be difficult to implement and the performance will suffer.

2. Investment and financing. Funding is required for new rural residence construction as well as for new industry formation. If the funds are too limited to support rural land redevelopment and to 
provide primitive capital for rural development, then the project will not be implemented despite the willingness of stakeholders to participate in rural renewal. Additionally, the investment and financing stage is related to interest distribution because it determines who should bear the costs and therefore has an impact on the final interest structure among actors.

3. Implementation. A set of management arrangements is required to control and monitor stakeholders' actions during rural renewal to prevent free-riders and other opportunistic behaviors and ensure that the funding of rural renewal can be spent effectively and the scheme can be implemented according to the time schedule. Otherwise, the goal of rural renewal will not be fulfilled and all stakeholders will suffer from interest loss in the end.

4. Revenue distribution. This stage is the last and another key step of rural renewal. Revenue distribution indicates the outcomes of rural renewal and provides evidence required to assess whether rural-urban integration has been facilitated. The upgrading of rural physical conditions provides evidence of the revenue growth of farmers and the rural area. Enabling urban areas to repay rural areas, increasing farmers' income and stimulating rural industrial transformation suggest that farmers and rural areas have attained a larger proportion of revenue and that the rural-urban social wealth gap is narrowing.

\subsubsection{Key Elements: Transactions, Actors, Governance Structures}

In the IoS framework, whose action arena is rural renewal, three key elements represent the entry points to explore the determinants of governance fit and demonstrate the performance differences in the context of rural-urban integration (Figure 1).

1. Properties of transactions. In this paper, the four stages of rural renewal are regarded as transactions. Williamson (1991) identified three types of transaction properties: specificity, uncertainty and frequency. In addition, the three classic properties pertain to nature-related transactions [29]. Hagedorn et al. (2002) and Hagedorn (2008) further reveal the properties of nature-related transactions, such as complexity, absence of separability and irreversibility [22,25]. Moreover, the transaction properties can be revealed to distinguish the physical and social attributes of rural renewal (Table 1).

Table 1. Properties of transactions.

\begin{tabular}{ccccc}
\hline & \multicolumn{3}{c}{ Properties of Transactions } \\
\cline { 2 - 4 } & Complexity & Specificity & Uncertainty (I) & Uncertainty (II) \\
\hline Scheme design & $\sqrt{ }$ & $\sqrt{ }$ & \\
Investment and financing & & $\sqrt{ }$ & $\sqrt{ }$ \\
Implementation & & & & $\sqrt{ }$ \\
Revenue distribution & & & & \\
\hline
\end{tabular}

First, because rural renewal is a systematic project, its scheme should arrange land redevelopment or land use structure readjustments and must be compatible with the diverse interests and demands of stakeholders as well as those of the ecological system involved. Obviously, complexity is the nature-related property of the scheme design. Moreover, the scheme of rural renewal cannot easily meet the local conditions in the specific area because of bounded rationality and incomplete information, which reflect another type of transaction property: uncertainty (I), which originates from cognitive limitations [27]. Second, rural renewal usually requires a large amount of money and the investment span is rather long and thereby results in high opportunistic costs. The investment is not available for other alternative uses during rural renewal; therefore, asset specificity is a typical property of the investment and financing stage. In addition, the capital capability of the specific investor or the region may affect the extent of asset specificity.

Third, rural renewal is based on land-scale redevelopment, which leads to a lock-in effect, meaning that without accessing all the land in the project area to enforce land redevelopment, the former investment of land assembly would be in vain. In other words, the implementation of rural renewal 
depends on land with a specific location, suggesting a type of specificity. Furthermore, uncertainty (II) is the property of implementation and it characterizes a situation in which the probabilities of specific actions leading to outcomes are unknowable, although the set of actions and the set of outcomes are still assumed to be finite and knowable [27]. For example, actors may not sure of the extent to which the rural renewal can be bindingly implemented in accordance with the scheme and the probability of conflicts during the implementation. Fourth, uncertainty (II) is a property of revenue distribution as well because actors do not know the probability of ex-post interest conflicts.

2. Characteristics of actors. The fulfillment of rural renewal requires certain actions of related actors. Actors of rural renewal have various characteristics, including the scale of the actors, i.e., the quantity of farmers participating in rural renewal; the extent of interest homogeneity, i.e., considerable mutual interest, little mutual interest, interest divergence and the extent of voluntariness, such as whether the actors are compelled to attend the renewal; and the extent of social capital, i.e., whether the community has formed a type of reciprocal connection and whether the reputation effect makes sense.

3. Governance structures. Governance structures are the practical organization and management modes for driving rural renewal. Governance is an effort to craft order and mitigate conflicts and realize mutual gains [30]. Market, hierarchy and hybrids are the generic governance structures that have different costs and competences [29]. To drive rural renewal, a market with decentralized features can create an incentive and a hierarchy with high-powered control can coerce. In addition, hybrids that combine incentives and coercion can also be applied to drive rural renewal.

\subsubsection{Governance Fit and Performance Differences}

Considering the IoS framework for rural renewal, aligning governance structures with the properties of transactions and characteristics of actors is the basic logic underlying governance fit, as shown on the left side of dash line in Figure 1. In order words, the social construction of governance structures depends on the properties of transactions and the characteristics of actors [21].

More specifically, different properties of transactions demand different types of governance. To reduce transaction costs and improve process efficiency, the governance structures should be aligned with the properties of transactions [29]. An increase in specificity increases the difficulty of compromising and strengthens the lock-in effect that often induces opportunistic behavior, such as hold-out behavior [31]. An increase in uncertainty (I) exacerbates the desire for more information [31], an increase in uncertainty (II) increases the desire for adaptation to disturbances and may cause the hazard of maladaptation [29] and an increase in complexity enhances the need to balance and coordinate the interests among actors as well as the relations among economy, society and ecology [22]. Therefore, in the stage of scheme design, high levels of complexity and uncertainty (I) demand governance structures with decentralized features to provide a platform for coordinating multiple interests as well as reducing information costs. For the three other stages, high levels of specificity and uncertainty (II) require governance structures with higher-powered control to facilitate rapid compromise and proper adaptations and prevent opportunistic behavior.

In addition, the characteristics of actors influence the potential supply of governance structures. For example, actors at a small scale with a high extent of voluntariness, interest homogeneity and profound social capital are more likely to enforce rural renewal in a self-organized manner $[28,32,33]$. A small scale of actors and high extent of interest homogeneity reduce the coordination cost of collective action and a small scale of actors provides incentive for collective action because it increases the revenue that each actor gains from collective action and it is also suitable for supervision that prevents opportunistic behavior, such as free-riding. The voluntariness of actors saves enforcement costs. Moreover, social capital plays a role in reinforcing consensus among actors and coordinating collective action.

Further, governance structures with differentiated costs and competence are bound to distinguish the performance of rural renewal, as shown on the right side of dash line in Figure 1. Briefly, once the specific governance structure is selected, the process efficiency of rural renewal, the direct outcomes of 
improved physical conditions and the wealth distribution effects will be jointly identified in general. In the context of rural-urban integration, several key pieces of evidence are available on the physical outcomes, distribution effects and process efficiency of different rural renewal modes. For the physical outcomes, the main evidence is whether the rural renewal mode successfully ameliorates the physical conditions of a rural area to enable farmers to have an equivalently high living quality as urban citizens. The main evidence for distributional effects is whether the rural renewal mode properly triggers the social wealth transfer to rural areas and realizes rural development and the main evidence of process efficiency is whether the rural renewal mode facilitates rural-urban integration via reduced transaction costs so that extra costs that might outweigh the benefits are not incurred [34,35].

For example, hierarchy is typical of high-powered control capable of enforcing rural renewal from the top down, thereby saving costs from over bargaining and opportunistic behavior [29]. Thus, the top level or authority also controls the revenue distribution, which leaves the equity of distribution in question. In addition, hierarchy often leads to costs associated with decision failures because of its inborn disadvantages, such as asymmetric information among layers and the bounded rationality of decision makers, which reduce the process efficiency [35]. Hybrids, such as self-organization with a combination of centralization and decentralization, are able to manage complex interest relations to pool resources, achieve moderate incentives and enable actors to create wealth together and then share revenue [36]. Furthermore, hybrids' internal decentralized mechanism can make full use of dispersed local knowledge, namely allow "man on the spot" to make decisions [37].

\section{Research Methods}

The case study and comparative analysis methods are applied in this research. First, we narrate each case in detail, including the entire rural renewal process, the actors' characteristics and their actions, costs and revenue distributions. Second, we illustrate the determinants of governance fit by comparative analysis. Third, given the context of rural-urban integration, we elaborate the performance differences, such as physical outcomes, distribution effects and process efficiency, of each rural renewal mode.

\subsection{Case selection and Survey Method}

As mentioned above, rural renewal in China can be categorized into two main types: government-led or self-organized rural renewal. We select two cases, one in each category, according to the criteria for typical case selection along with expert advice and our own experience [38]. The two cases are rural land consolidation of $\mathrm{H}$ Village in Jiashan County, Zhejiang Province and rural construction land transfer and tourism development of S Village in Jintang County, Sichuan Province.

We conducted the fieldwork in Jiashan County, Zhejiang Province and in Jintang County, Sichuan Province from 2012 to 2014. During the fieldwork, county-level officials governing rural renewal introduced relevant rules and provided general information about the projects in their counties. These officials also recommended the cases for further study. Subsequently, we started to conduct the semi-structured interviews in H Village and S Village. To select interviewees, we adopted the stakeholder-based approach [39] and interviewed village leaders, village elites, township-level officials and farmers involved in or affected by rural renewal. We particularly focused on the scheme design, investment and financing, implementation and revenue distribution stages as well as the interviewees' attitudes and comments on rural renewal. The interviews among different actors also served to cross-check information. All the information provides the basis for further case studies and comparative analyses.

\subsection{Comparative Analysis Method}

The comparative analysis of our research consists of three steps according to the IoS framework. Initially, we distinguish the properties of transactions and the characteristics of actors and then make two tables. One table displays the level of specificity, uncertainty and complexity regarding 
each transaction and another displays the scale of the actors as well as the extent of voluntariness, interest homogeneity and social capital.

Next, we analyze the features of governance structures and assess their performance. We concentrate on the performance of governance structures in the cases, including (1) whether they achieved equity among physical conditions, such as planning appropriate rural residential areas and providing sufficient infrastructure for production and living; (2) whether they narrowed the social wealth gap between rural and urban areas, such as releasing the potential value of rural land and then allowing farmers and rural areas to share greater land revenue and accumulate sufficient funds and capital for sustainable development; and (3) whether they drove rural-urban integrated development in a high process efficiency manner, such as by reducing the transaction costs for information, decisions, negotiations, coordination and monitoring. Thus, the other table was created to present our findings.

Finally, we reveal the impacts that diverse properties of transactions and characteristics of actors have on the selection of governance structures and compare the performance of different rural renewal modes via two cases analyses. Thus, according to the table summarizing all the above findings, we explain the logic of governance fit and present the performance differences of rural renewal with regard to rural-urban integration. As such, the research questions can be simultaneously addressed.

\section{Rural Renewal in Contemporary China: Two Typical Cases}

\subsection{Government-Led Rural Renewal in H Village, Zhejiang Province}

\subsubsection{Background}

$\mathrm{H}$ Village is located in northern Jiashan County, a well-developed area in Zhejiang Province. In 2011, the GDP of Jiashan County was 32.14 billion yuan, along with the public finance income over 2.43 billion yuan while its urban-rural income gap was 1.95:1 (Adopted from http:/ / www.tjcn. org $/ \mathrm{tjgb} / 11 \mathrm{zj} / 23592 . \mathrm{html}$ ). For a long time, the income of the village was generated from livestock breeding and over $90 \%$ of the village households were engaged in this profession. The residences and other buildings in the village were constructed in the 1980s and 1990s and they were all in bad or even dangerous condition (Figure 2). Thus, the physical conditions of the village obviously required improvement.

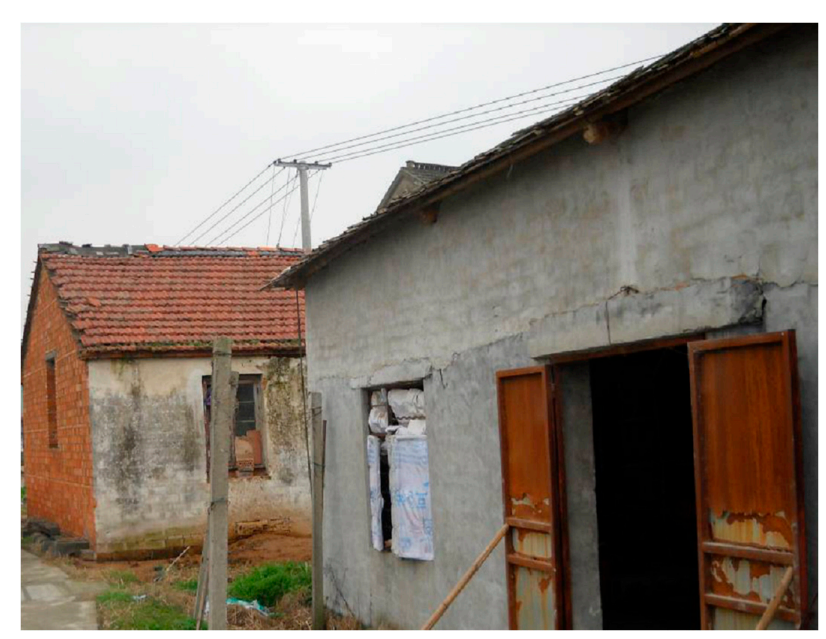

Figure 2. Rural residences before renewal.

Additionally, many residences in H Village were underused or not used because an increasing number of farmers had migrated to urban areas to earn a living in recent years; however, Jiashan County experienced rapid economic development similar to many other counties in eastern China; thus, a large amount of construction land was required. Therefore, the rural-urban land use structure in this area 
urgently needed to be optimized. The policy of Linkage between Urban Land Taking and Rural Land Giving (LUTRG) provided an opportunity for such optimization and it consists of a spectrum of land use changes led by the government [40,41]. Rural construction land is re-planned, consolidated and readjusted. A portion of the land is utilized for farmer residences in a more intensive way, such as the construction of multi-story buildings. The government fulfills LUTRG quotas by restoring the remainder of the land back to cultivated land and then authorizes extra farmland conversion for urban land supply. Farmers and rural areas obtain compensation by fulfilling the LUTRG quotas.

Based on the area's background, H Village renewal was conducted in the form of rural land consolidation to improve rural living conditions and increase land use efficiency.

\subsubsection{The Process of Rural Renewal}

As the sponsor and organizer, the local government arranged the entire process of rural renewal, including the scheme design, investment and financing, implementation and revenue distribution stages. Initially, the local government planned for rural land consolidation and designed a detailed scheme for $\mathrm{H}$ Village renewal and all files were sent to an upper government level for approval. The scheme determined the scale of rural renewal. The entire project covered $199.37 \mathrm{mu}$ (One hectare equals $15 \mathrm{mu}$.) land and 279 households. The scheme planned for the rural renewal to be conducted as a new rural-urban integrated community by restoring construction land for residences back to cultivated land and relocating farmers to a newly built and modernized intensive residential area.

Next, the local government actively took responsibility for the investment and financing stage. The cost of $\mathrm{H}$ Village renewal was nearly 59.04 million yuan, including more than 35.44 million yuan for compensating relocated rural households and 19.10 million yuan for constructing a new rural residential area. The local government was able to afford all costs upfront based on the county-level public budget and loans from the local bank. Subsequently, rural households would afford the financial costs of constructing new rural residential area.

The local government also established a top-down administration system that included the leading group at the township level and the expertized working group at the village level to implement the rural renewal. The township-level government focused on compensating the relocated households, restoring rural residential land to cultivated land and constructing new residences. The village committee of $\mathrm{H}$ Village assisted the government in enforcing rural land consolidation, including propagating policies and persuading farmers to remove of their old houses. Although farmers are the key actors of rural renewal, they lacked the right to make decisions. The project was approved in December 2010 and completed in November 2013, for a total span of 3 years. Overall, the implementation of H Village renewal was successful and farmers compromised without any major conflicts.

Finally, as for revenue distribution, the local government benefited from the LUTRG policy. After restoring the rural residential land back to cultivated land, the local government fulfilled the LUTRG quotas of converting $57.77 \mathrm{mu}$ cultivated land to construction use, thereby relieving the pressure associated with quotas for newly added construction land and boosting the local economy. The local government supplied land to the land users of secondary industry at the price of 0.3 million yuan/mu by using $23.11 \mathrm{mu}$ of the LUTRG quotas and supplied land to the land users of tertiary industry at the price of 1 million yuan/mu by using the remainder $(34.66 \mathrm{mu}$ ) of the quotas. In total, the local government earned more than 41.59 million yuan from applying the LUTRG quotas to farmland conversion and urban construction land leasing. Moreover, the annual tax income of newly added construction land (57.77 mu in total) was 75,000 yuan/mu since 2013 and in 3 years, the annual tax income would grow to 84,000 yuan/mu. As such, the local government has gained more than 4.33 million yuan/year since 2013 and it would gain more than 4.85 million yuan/year after 3 years.

Rural renewal indeed improved the physical conditions of $\mathrm{H}$ Village, especially the living quality (Figures 3 and 4). The newly built apartments were modernized, the layout of the apartments was reasonable and the high-story apartments were equipped with elevators. The infrastructure 
of the new rural residential area was the same as that in the urban residential area and the roads, green space, garages and the public activity arena were well equipped. According to the compensation standard for relocation set by the local government, the average total compensation for each household was 127,000 yuan. The average net revenue of each household reached 58,500 yuan after paying the costs for new residences (average 68,500 yuan per household). However, the new residential area was far from the original site of $\mathrm{H}$ Village, where the farmland was located. Consequently, the commuting distance for farming (the total distance is $10 \mathrm{~km}$ ) was increased and thus inconvenient for farmers. Moreover, after moving into the apartments, the traditional method of production, i.e., livestock breeding, was difficult to continue because of the loss of yards and pools. Certain farmers without alternative methods of earning a living were confronted with greater challenges. Moreover, farmers also complained about the change of living conventions because they found it difficult to acclimate to living in the apartments.

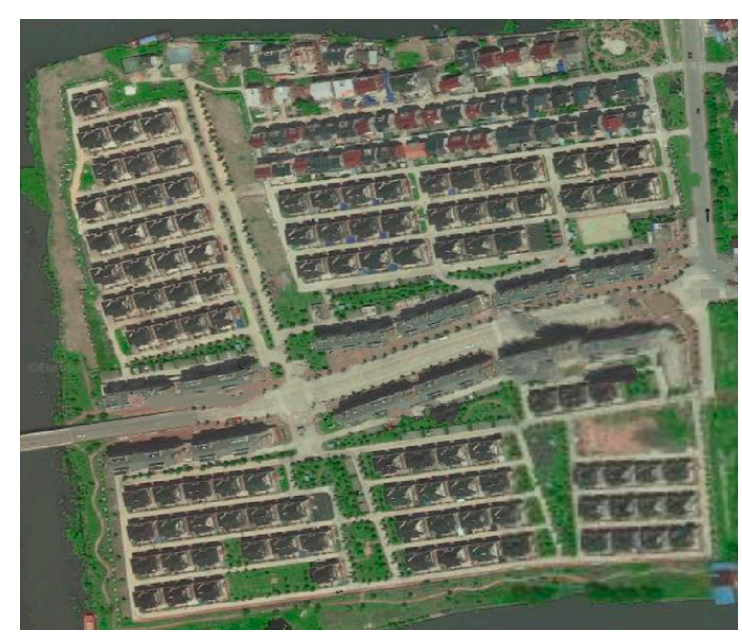

Figure 3. New rural residential area.

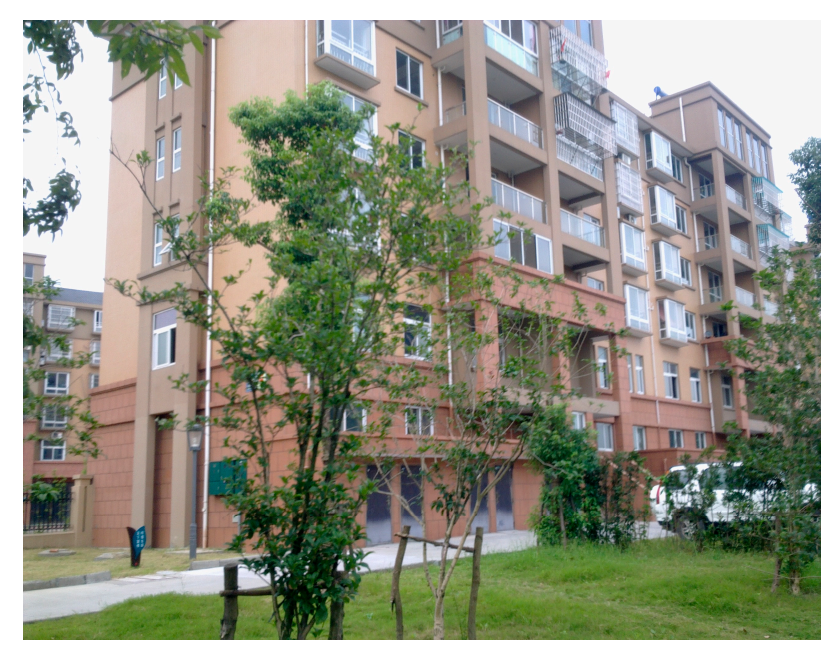

Figure 4. Rural residences after renewal

\subsubsection{Summary}

The rural renewal in $\mathrm{H}$ Village is a typical government-led mode. In the stage of scheme design, the government solely designed and approved the scheme for rural renewal in $\mathrm{H}$ village. In the stage of financing and investment, the government played the role of investor and was able to afford the entire cost of rural renewal. In the stage of implementation, the government established a set of hierarchical 
management systems to enforce rural renewal. In the stage of revenue distribution, the government obtained the distribution advantages.

As a result, although the scale of $\mathrm{H}$ Village renewal was large, it required only approximately 3 years, suggesting the high efficiency of the government-led mode. However, the large scale of demolition and construction, the dramatic change of production and living traditions and the instability of farmers' livelihood represented potential hazards underlying the high efficiency of government-led rural renewal.

\subsection{Self-Organized Rural Renewal in S Village, Sichuan Province}

\subsubsection{Background}

S Village is situated in Jintang County and belongs to the third layer of Chengdu City which is the capital of Sichuan Province. In 2011, the GDP of Jintang County was 16.42 billion yuan, its public finance income was 0.96 billion yuan, with the urban-rural income gap up to 2.19:1 (Adopted from http:/ / www.tjcn.org/tjgb/23sc/24575.html). Despite the remote location, the village is in proximity to Zhualong Stream and its landscape and ecology are of high quality, which attracts an increasing number of urban citizens to the village for vacations. However, the infrastructure and living conditions of S Village were inferior for a long time. The region experienced the great earthquake on 12 May 2008 and many houses in S village were damaged to various extents. One of the farmers named $\mathrm{Wu}$ (a village elite), which was also an entrepreneur, intended to construct a village hotel to develop rural tourism in S Village with the purpose of repaying his homeland and his plan was strongly supported by the local government and the village. Moreover, as a model for farmer autonomy, the village has established a completed coordination mechanism that includes proposals, discussions, decision making and enforcement during the long period of farmer autonomy.

Based on the area's background, farmers of S Village implemented rural renewal on their own, although it was led by the village committee and village elite.

\subsubsection{The Process of Rural Renewal}

The village elite $\mathrm{Wu}$, village committee and farmers were the stakeholders of S Village renewal. Initially, $\mathrm{Wu}$ acted as an initiator and designed the rural renewal scheme and he considered the other farmers' opinions. The final version of the scheme consisted of the scale of renewal (i.e., $33.26 \mathrm{mu}$ and 37 households from the same group), the plan of the new rural residential area and the future development direction of the village. The scheme clarified the rural renewal route, which occurred by re-planning and readjusting the rural residential land after farmers moved out of their old houses, relocating the farmers with a small proportion of readjusted land and then constructing a village hotel to develop tourism by transferring the remainder of the land to $\mathrm{Wu}$.

During the scheme design, the 37 households took the advantage of the coordination mechanism that was established during the long process of farmer autonomy. The households agreed to pool together all their land assets, including old houses, rural residential land and other types of constructions and land, to generate a bundled price after reaching a consensus by collective discussion. Subsequently, each household proposed their own compensation requirements according to the type, structure and size of the land property to determine the bundled price range favored by all the households. Finally, as the representative of the 37 households, the village committee negotiated and bargained with $\mathrm{Wu}$ to determine the price for the rural construction land transfer. The price was much higher than the land acquisition compensation (average 17,400 yuan/mu) (Adopted from http:/ / www.cdlr.gov.cn/Zizhan/List.aspx?ClassID=001007017001014002\&ModuleNo=001007017) in Jintang County for the sake of fully considering the farmers' interest. Moreover, each household had the right to decide whether to participate in rural renewal depending on the outcome of negotiation with $\mathrm{Wu}$. Consequently, no conflicts associated with compensation occurred in the subsequent process. 
During the investment and financing stage, $\mathrm{Wu}$ collected money for the rural renewal. The investor was the Modern Agriculture Company founded by Wu. The total cost of S Village renewal was approximately 31.19 million yuan. Rural construction land consolidation and village hotel construction cost approximately 26 million yuan. The cost of acquiring rural construction land, i.e., the total price of the land transfer, was approximately 4.19 million yuan, most of which was used to construct a new rural residential area for the farmers. The construction of roads, water pumps and electricity lines in the new rural residential area cost approximately 1 million yuan.

Subsequently, the investor consolidated the $33.26 \mathrm{mu}$ of rural construction land and then a small part of construction land (approximately $10 \mathrm{mu}$ ) was used for the construction of new houses by the farmers themselves according to the plan that was collectively decided on by the 37 households. The remainder of the land (approximately $23.26 \mathrm{mu}$ ) was transferred to the investor, Modern Agriculture Company, for the village hotel construction at the price of 180,000 yuan/mu at the Chengdu Property Rights Transaction House. The project began at the end of 2010 and was completed at the end of 2013. During the implementation, all the farmers actively cooperated and no one withdrew or required additional economic interest, i.e., asked for higher compensation or more land for relocation.

Currently, the village hotel has been established and is in operation (Figure 5) and it was recognized as a Five Star Hotel by the local tourism administration department. Wu planned to enlarge the scale of the hotel, perfect the equipment and foster additional industries in the near future with the aim of establishing a regional brand and accelerating tourism development. In addition, the new rural residential area was completed and all farmers moved into the newly built townhouses (Figure 6).

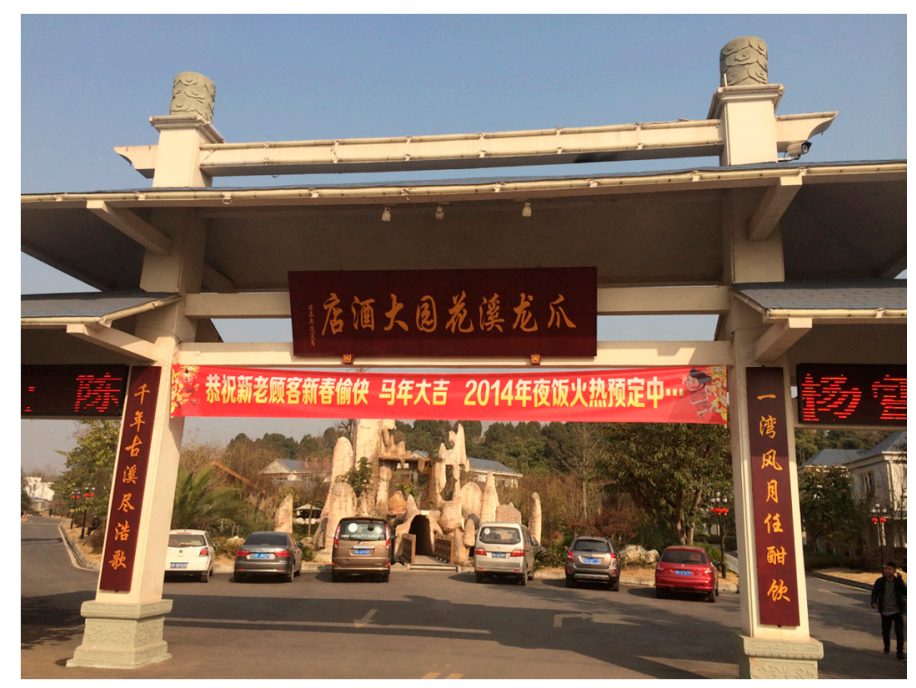

Figure 5. Village hotel.

Finally, in the stage of revenue distribution, the farmers received income from the rural construction land transfer and shared the land revenue provided by the rural renewal. Most households gained more than 100,000 yuan, which was more than the cost of building their own new residences. Other households with a relatively small size of rural residential land gained tens of thousands of yuan, which was sufficient to construct new houses. Furthermore, the physical conditions, especially the living conditions in S Village, were greatly improved because old and damaged houses were replaced by newly constructed homes and the infrastructure and public facilities, such as roads, water pumps, light and green open space, were also improved (Figures 6 and 7). 


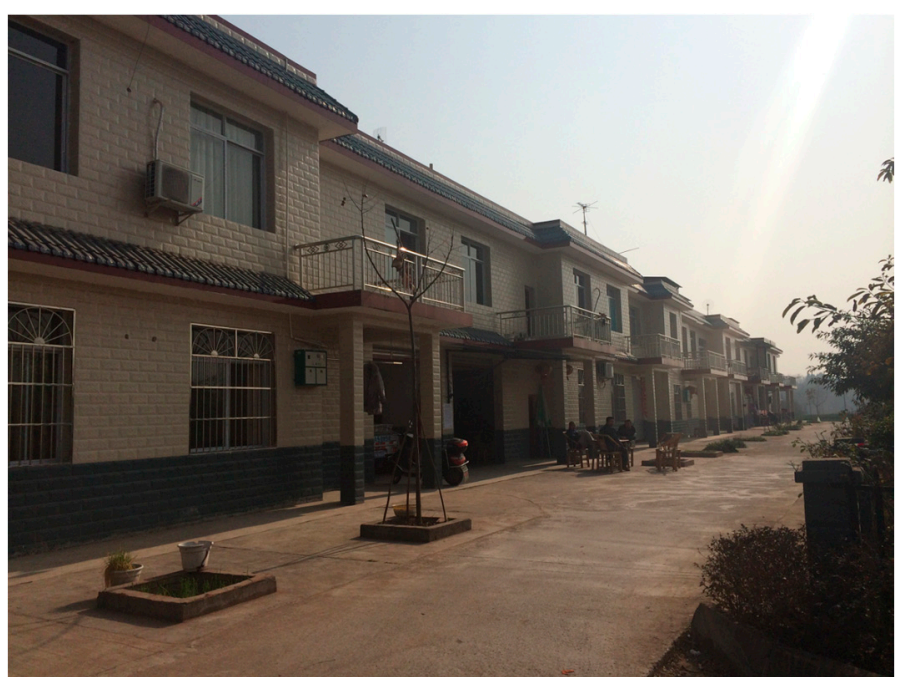

Figure 6. Rural residences.

Additionally, more than 120 farmers (the total number of farmers in S Village is 304) were employed by the village hotel, which ensured the farmers' livelihood, increased the farmers' income and gradually promoted the transformation of industry from agriculture to non-agriculture. The interviewees did not express any negative comments on the performance of $S$ Village renewal. In addition, the income stream of rural renewal would continuously flow to the investor because of the operation of the village hotel and future prospects for rural tourism.

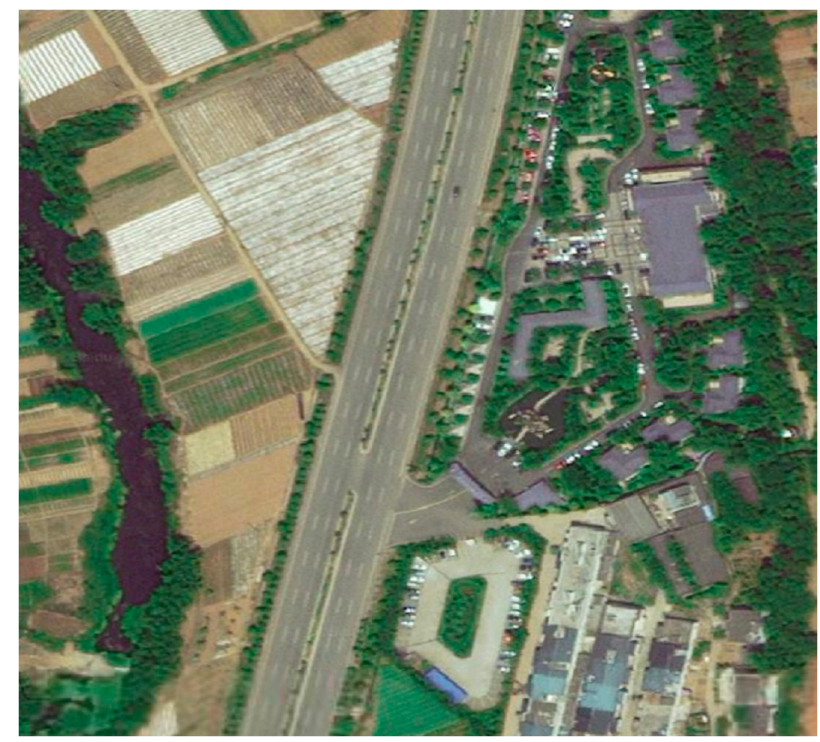

Figure 7. Village hotel and new rural residential area.

\subsubsection{Summary}

S Village renewal showed the typical features of self-organization. In the stage of scheme design, the village elite designed the scheme for rural renewal in S village based on the farmers' opinions. The coordination mechanism played an important role and the village committee representing the farmers negotiated with the village elite to reach a consensus on critical issues. In the stage of financing and investment, the village elite played the role of investor and were able to afford the entire cost of rural renewal. In the stage of implementation, the project was automatically organized 
and implemented by the households, who were guided by the village committee and village elite. In the stage of revenue distribution, a reasonable interest structure was realized.

As a result, the farmers shared the land revenue and the living conditions were improved enormously (Figure 7). The investor, i.e., the village elite, achieved their goal and gained long-term revenue. The physical conditions of S Village were upgraded and the village shifted to a new path of tourism development, indicating that the rural industry transformation was successfully underway.

\section{Comparison between the Two Cases}

In general, the governance fit of rural renewal in H Village and S Village varied for different reasons and contributed to different performances.

\subsection{Transaction Properties}

The scheme design of $\mathrm{H}$ Village renewal was more complicated than that of S Village (Table 2) because the scale of $\mathrm{H}$ Village renewal was larger, with the project area encompassing $199.37 \mathrm{mu}$, whereas the scale of S Village renewal encompassed only $33.26 \mathrm{mu}$. The larger scale of rural renewal meant that more types of interest, e.g., economic, social and ecological relations, had to be considered and coordinated, which added to the complexity of the scheme design. Additionally, the limited cognitive capability of designers in both cases led to a high level of uncertainty (I) regarding the scheme design because the appropriateness or the feasibility of the scheme in this stage was difficult to determine (Table 2).

Table 2. Transaction properties.

\begin{tabular}{ccc}
\hline Properties & H Village & S Village \\
\hline Scheme design \\
complexity \\
uncertainty (I) & ++ & + \\
Investment and financing \\
specificity & + & + \\
\hline $\begin{array}{c}\text { Implementation } \\
\text { specificity } \\
\text { uncertainty (II) }\end{array}$ & + & ++ \\
\hline Revenue distribution \\
uncertainty (II)
\end{tabular}

In the stage of investment and financing, the level of asset specificity in S Village was higher than that in H Village (Table 2). The total cost of H Village and S Village were approximately 59.04 million yuan and 31.18 million yuan, respectively. Intuitively, the cost of $\mathrm{H}$ Village renewal was slightly more than that of S Village, indicating that the asset specificity of $\mathrm{H}$ Village renewal was slightly stronger. However, the investment of $\mathrm{H}$ Village renewal was not a heavy financial burden for the local government because Jiashan County, which is in the developed eastern part of China, reported a GDP totaling 32.14 billion yuan in 2011 (Adopted from http:/ / www.tjcn.org/tigb/11zj/ 23592.html) and the public finance income for the county-level government, which was the investor of $\mathrm{H}$ Village renewal, was more than 2.43 billion yuan (Adopted from http:/ / www.tjcn.org/tigb/11zj/ 23592.html). Incontrast, Jintang County, in the less developed western part of China where S Village is situated, reported a GDP (Refer to http:/ / www.tjcn.org/tigb/23sc/24575.html for details.) that was only half as high as the GDP reported by Jiashan County in 2011 and the investor of S Village renewal was a private enterprise founded by $\mathrm{Wu}$; thus, the capital capability of the investor in $\mathrm{S}$ Village was much weaker than that in H Village. In other words, compared with the government in a developed region, if a private enterprise in a less developed region is required to invest a substantial amount of 
money into rural renewal, it would not be able to afford other types of investment, which heightened the level of asset specificity.

During the implementation stage, the land asset specificity of $\mathrm{H}$ Village renewal was stronger than that of S Village (Table 2). The scale of H Village renewal was much larger, suggesting that more land had to be acquired. As the acquisition of land increased, the investor had to rely more heavily on land with a specific location (i.e., lock-in effect); thus, these transactions were more likely to be the victim of opportunistic behavior. Put another way, if a land owner decided to hold out on transferring, then the investor who had acquired a large amount of land would suffer from project suspension because of a lack of necessary land. Such a scenario reflects the high level of specificity and its hazards. Additionally, both H Village and S Village faced a rather high level of uncertainty (II) (Table 2), such as the probability that rural renewal would be implemented in accordance with the scheme and the probability of conflicts during implementation. In the stage of revenue distribution, both cases were also confronted with a high level of uncertainty (II) (Table 2). Certain unanticipated issues occurred, such as the probability of further conflicts incurred by distribution.

\subsection{Characteristics of the Actors Involved}

First, fewer actors were involved in the S Village renewal than in the H Village renewal (Table 3). Only 37 households participated in the rural renewal in S Village, whereas 279 households participated in the rural renewal of H Village. Second, the extent of the actors' voluntariness in S Village was stronger than that in H Village (Table 3). Specifically, in S Village, the rural renewal was initiated by the village elite and obtained profound support from the farmers and the farmers had the right to decide whether to participate in the project based on their own willingness. However, in $\mathrm{H}$ Village, the project was initiated and supported by the local government with coercive administrative commands. The government established the leading group and working group to drive the project and the government constructed and approved the scheme of rural renewal, regardless of the farmers' opinions. The rights of farmers were restricted and farmers became solely passive participants.

Table 3. Characteristics of the actors.

\begin{tabular}{ccc}
\hline Characteristics & H Village & S Village \\
\hline Scale & + & - \\
Voluntariness & - & + \\
Interest & - & + \\
homogeneity & & + \\
Social capital & - & + \\
\hline Note: - denotes small/weak; + denotes large/strong.
\end{tabular}

Third, the extent of homogeneous interest among the actors was stronger in S Village than that in H Village and more social capital was accumulated in S Village as well (Table 3). As a model village of farmer autonomy, the collective coordination mechanism of $\mathrm{S}$ Village was conducive to mitigating the diverging interest among actors [42,43]. Furthermore, all farmers participating in the project had been neighbors for many years. They were familiar with each other and experienced frequent interactions, including daily communication, work cooperation, etc.; thus, we can infer that trust and strong social ties formed among the farmers. Therefore, a considerable amount of social capital had been accumulated to generate cooperation and reciprocity. However, many farmers in $\mathrm{H}$ Village had migrated to urban areas and interacted less with each other than before, which led to different interests among actors and weakened social network of the traditional rural community [44]. Consequently, the social capital in $\mathrm{H}$ village was gradually eroded. 


\subsection{Cost and Competence of Governance Structures}

In the case of $\mathrm{H}$ Village, the local government established the leading group and working group at the township level and village level and it relied on top-down administrative commands to coordinate the entire process of rural renewal, including relocation, compensation and new residence construction. Led by the local government, the performance of $\mathrm{H}$ Village renewal was remarkable in improving the physical conditions (Table 4). Farmers moved out of their old houses, which presented poor living conditions and moved into new houses in the new residential area. The new residential area for farmers consisted of modern apartments with well-designed layouts, a scenic environment and well-equipped infrastructure (Figures 3 and 4). Obviously, it achieved the equity of rural-urban physical living quality to a great extent.

Table 4. Cost and competence of governance structures.

\begin{tabular}{|c|c|c|}
\hline & H Village & S Village \\
\hline Features & Government-led & Self-organized \\
\hline \multirow{4}{*}{ Physical outcomes } & Modern apartments & Townhouses \\
\hline & Well-organized layout & Well-organized layout \\
\hline & Neat environment & Neat environment \\
\hline & $\begin{array}{l}\text { Well-equipped infrastructure and public } \\
\text { facilities }\end{array}$ & $\begin{array}{l}\text { Well-equipped infrastructure and } \\
\text { public facilities }\end{array}$ \\
\hline \multirow{9}{*}{ Distribution effects } & Government: & Farmers and rural area: \\
\hline & $\begin{array}{l}\text { Quotas revenue approx. } \\
41.59 \text { million yuan }\end{array}$ & $\begin{array}{l}\text { Land transfer revenue approx. } \\
4.19 \text { million yuan }\end{array}$ \\
\hline & $\begin{array}{l}\text { Income from the construction of new } \\
\text { residences approx. } 19.10 \text { million yuan }\end{array}$ & New residences \\
\hline & $\begin{array}{l}\text { Direct tax revenue approx. } 4.33 \text { million } \\
\text { yuan in } 2013\end{array}$ & Creation of 120 jobs \\
\hline & $\begin{array}{l}\text { Direct tax revenue approx. } 4.85 \text { million } \\
\text { yuan in } 3 \text { years }\end{array}$ & $\begin{array}{l}\text { Consumption revenue from urban } \\
\text { citizens touring in rural area }\end{array}$ \\
\hline & Farmers and rural area: & \\
\hline & $\begin{array}{l}\text { Net compensation for relocation } \\
\text { (deducting payment for new residences) } \\
\text { approx. } 16.34 \text { million yuan }\end{array}$ & \\
\hline & New residences & \\
\hline & Instability of livelihood & \\
\hline \multirow{4}{*}{ Process efficiency } & Approximately 3-years to complete & $\begin{array}{l}\text { Approximately 3-years to } \\
\text { complete }\end{array}$ \\
\hline & No hold outs & No hold outs \\
\hline & No conflicts & $\begin{array}{l}\text { No additional interest } \\
\text { requirements }\end{array}$ \\
\hline & Decision deficiencies & No decision deficiencies \\
\hline
\end{tabular}

In addition, the local government controlled the revenue distribution. The government had the power to devise the standard for compensating the relocated farmers and directly distribute the land revenue induced by rural renewal, its investment in rural renewal (approximately 59 million yuan) was covered and net revenue was gained based on the direct income earned by utilizing the LUTRG quotas from the project to lease land to secondary and tertiary industries as well as by obtaining payments for new residences from farmers. In the long term, this pattern would accelerate the local economic development by exploiting LUTRG quotas to attract investments from enterprises and promote industrialization and urbanization. As a result, the local government even gained long-term revenue from the rural renewal in the form of taxes (Table 4). 
However, farmers temporarily attained only limited social wealth induced by the rural renewal in the form of compensation and new residences. In addition, the traditional production system of livestock breeding had to be given up after farmers moved into the apartments because of the inadequate space and a number of farmers failed to find a new method of earning a living. Thus, the rural renewal in $\mathrm{H}$ Village even exerted a negative impact on farmers' livelihood to some extent. Overall, the government-led rural renewal in H Village transferred the social wealth to the rural area only once and in an unsustainable way and its performance regarding the facilitation of rural development did not meet the requirements of rural-urban integration (Table 4).

Nevertheless, the government limited the farmers' opportunity sets by applying coercive public power to prevent the actors from displaying opportunistic behavior, such as holding out. Therefore, the project span of the $\mathrm{H}$ Village renewal with a large scale and heavy workload was nearly equivalent to that of the $S$ Village renewal with a small scale and light workload. In addition, under the strict supervision of the government, the scheme of $\mathrm{H}$ Village renewal was implemented bindingly and conflicts never occurred, although it presented issues related to incomplete information and the bounded rationality of decision makers at the upper levels. For instance, the new residential area was far from the agricultural area, which made it inconvenient for farmers to perform daily work and some farmers could not acclimate to the new way of life. Many farmers complained about these issues in their interviews. The above issues suggest that government-led rural renewal may induce ex-post transaction costs, such as decision deficiencies and may exaggerate the process efficiency loss (Table 4).

The self-organized rural renewal in S Village was distinguished by the following features: it was led by the village committee and village elite, it included farmer coordination and it provided for revenue sharing. Under the leadership of the village committee and village elite, local farmers organized themselves to change the extensive and scattered form of their previous living environment into an intensive and consolidated form and to utilize the land they saved to develop rural tourism by constructing a village hotel. The village elite took responsibility for providing roads, water pumps, electricity lines, green space and other infrastructure. In S Village, farmers now live in the new residential area instead of the old houses with inferior living conditions or damaged houses affected by the earthquake. The newly constructed residential area includes well-equipped townhouses with a well-organized layout and neat environment, thereby attaining the goal of upgrading the rural physical conditions (Figures 6 and 7 and Table 4).

The rural renewal in S Village was intriguing because of the revenue sharing distribution (Table 4). The farmers attending the project obtained all the land transfer income (average 180,000 yuan per mu), which was much higher than the land acquisition compensation standard (average 17,400 yuan per mu). The village elite as the land user spent 1 million yuan on providing the infrastructure for the new residential area; therefore, self-organization enabled the farmers to receive the highest direct revenue from rural renewal. In addition, S Village benefited from interest in rural tourism and the appropriate development strategy was able to reduce the side effects on farmers' livelihood caused by rural renewal that changes the traditional method of earning a living by providing approximately 120 jobs for farmers (the population of S Village is only 304). Moreover, this development strategy also attracted more people from the urban area to the rural area for vacations and then generated consumption revenue for the rural area. As such, the rural renewal in S Village positively shifted social wealth from the urban area to the rural area and it increased the farmers' income and transformed the rural industrial structure.

Additionally, the coordination mechanism nested in self-organization helped enhance the process efficiency of rural renewal (Table 4). In S Village, the farmers communicated their requirements for relocation compensation and resettlement and opinions on the plan for the new residential area and then balanced their diverse interests as well as restrained their self-interested motivations to fulfill the collective action through coordination. Consequently, the farmers were willing to pool their land property to form a bundled price and negotiate with the land user collectively. In addition, the farmers' living conventions and preferences for single houses were considered during the scheme design; 
therefore, townhouses rather than apartments were built in the new residential area. Thus, the effective coordination mechanism facilitated information communication and relieved potential conflicts of interest to form a fully considered, suitable and feasible strategy of rural renewal. Therefore, the process efficiency loss caused by decision deficiencies and opportunistic behavior was avoided. Moreover, issues such as hold-out problems at the implementation stage, additional compensation requirements after signing the land transfer contract and negative comments on the revenue distribution from farmers were not observed.

\subsection{Summary}

The two cases presented above demonstrate that the properties of transactions and characteristics of actors were the determinants of governance fit. Further, the performance of the government-led mode in H Village was undoubtedly distinct from that of the self-organized mode in S Village (Table 5).

The level of specificity in the implementation stage in $\mathrm{H}$ Village renewal was higher than that in $\mathrm{S}$ Village and H Village also faced a high level of uncertainty (II) in the stages of implementation and revenue distribution. The government-led mode controlled the span of bargaining among stakeholders and the occurrence of opportunistic behavior to complete the large scale of new countryside construction in a short time. In addition, no conflicts occurred during the rural renewal; therefore, it properly fit the governance demand for high-powered control under the high levels of specificity and uncertainty (II). The government-led rural renewal in H Village fully reflected the advantages of hierarchy by forcing actors to comprise and coordinate by strengthening control, weakening incentives and managing or even preventing potential conflicts to improve the process efficiency.

Additionally, although the level of specificity in the stage of investment and financing in $S$ Village renewal was higher than that in $\mathrm{H}$ Village and the levels of uncertainty (II) in the stages of implementation and revenue distribution were as high as in $\mathrm{H}$ Village, the nested coordination mechanism of the self-organized mode played a critical role in behavior control, thereby ensuring no hold outs and no extra interest requirements throughout the rural renewal. Moreover, self-organization was also able to weaken the incentives associated with opportunistic behavior and restrain the negative influence from uncertainty (II), thereby providing stakeholders with safeguards by relying on another type of high-powered control.

As for the distribution effects, the local government manipulated the entire $\mathrm{H}$ Village renewal process, including revenue distribution and it attained the distribution advantage in both the short term and long term via land leasing and taxes. However, the farmers and rural area received limited benefits. Furthermore, in H Village, ex-post costs of decision deficiencies occurred, suggesting that process efficiency was higher in the former period but subsequently decreased. Because of the bounded rationality of central decision makers and asymmetric information among layers, the top-down administrative command mechanism that hierarchy relies on is not able to align with the high complexity and uncertainty (I) of the scheme design.

Given the governance demand generated by the complexity and uncertainty (I) of rural renewal, self-organization was selected in S Village. The farmers together designed the scheme of rural renewal that was suitable for the local conditions by utilizing local knowledge and they also managed the complicated interest relations, such as the land transfer price and the new residence plan, via a coordination mechanism from the very beginning. Thus, the newly built residences lived up to the expectations of the farmers; the blueprint of rural tourism fit the local conditions; and the obstacles to project implementation, such as conflicts, were avoided. All these phenomena reflect the advantages of decentralized governance structures. Therefore, by reducing the information costs, avoiding decision failures and controlling the complexity and uncertainty (I) of the scheme design, the physical outcomes and process efficiency of rural renewal were improved. 
Table 5. Case comparisons.

\begin{tabular}{|c|c|c|}
\hline & H Village & S Village \\
\hline \multicolumn{3}{|l|}{1 Properties of transactions } \\
\hline \multicolumn{3}{|l|}{ 1.1 Scheme design } \\
\hline 1.1 .1 complexity & ++ & + \\
\hline 1.1.2 uncertainty (I) & + & + \\
\hline \multicolumn{3}{|l|}{1.2 Investment and financing } \\
\hline 1.2 .1 specificity & + & ++ \\
\hline \multicolumn{3}{|l|}{ 1.3 Implementation } \\
\hline 1.3.1 specificity & ++ & + \\
\hline 1.3.2 uncertainty (II) & + & + \\
\hline \multicolumn{3}{|l|}{ 1.4 Revenue distribution } \\
\hline 1.4.1 uncertainty (II) & + & + \\
\hline \multicolumn{3}{|l|}{2 Characteristics of actors } \\
\hline 2.1 Scale & + & - \\
\hline 2.2 Voluntariness & - & + \\
\hline 2.3 Interest homogeneity & - & + \\
\hline 2.4 Social capital & - & + \\
\hline 3 Governance structures & Government-led & Self-organized \\
\hline \multicolumn{3}{|l|}{4 Performance } \\
\hline 4.1 Physical outcomes & Built-up new countryside & Built-up new countryside \\
\hline 4.2 Distribution effects & One-time social wealth transfer & Sustainable social wealth transfer \\
\hline 4.3 Process efficiency & High at first but lower later & High \\
\hline
\end{tabular}

Note: - denotes weak/small; + denotes strong/large; ++ denotes stronger/larger.

Admittedly, self-organization cannot be realized without favorable characteristics among the actors. Compared with the actors of the H Village renewal, the scale of the actors was smaller in the S Village renewal, the extent of their voluntariness and interest homogeneity was stronger and social capital had accumulated to a greater extent. As a consequence, no ex-ante long-term bargaining occurred and the coordination cost of collective action was saved because of the small scale. Moreover, the small scale also allowed every actor to share a comparatively large proportion of private revenue, with most households earning more than 100,000 yuan from the land transfer, which exceeded the cost of building new houses. Obviously, the private revenue was attractive enough to provide the incentive for collective action. In addition, extra costs of enforcement were not incurred because of the high extent of voluntariness. Last but not least, the small scale was beneficial for monitoring and regulating and the social capital, such as the convention of reciprocity stemming from the long-standing practice of farmer autonomy, provided the informal rules for rural renewal, thereby illustrating one of the reasons why there were no hold outs or other conflicts of interest. Briefly, the characteristics of actors in the S Village renewal helped foster collective action to settle issues related to the initial supply of self-organization.

As for revenue distribution, farmers in S Village gained the most from the rural renewal and the rural renewal in S Village also continuously shifted the social wealth to the rural area because the operation of the village hotel and the development of rural tourism created off-farm income. All these factors contributed to narrowing the social wealth gap and facilitating rural development.

\section{Conclusions}

In the context of rural-urban integration, this study reveals the logic underlying the fit of governance with regard to rural renewal in contemporary China and illustrates the performance differences from the perspectives of physical outcomes, distribution effects and process efficiency. An IoS framework is developed and a detailed comparison between two typical cases is performed. The results indicate that (1) the properties of transactions and characteristics of actors mutually lead to the different governance structures (i.e., government-led mode and self-organized mode); (2) different 
governance structures result in different rural renewal performance. Two specific conclusions are listed below.

First, large scale of rural renewal induces high levels of specificity and unanticipated probability of various outcomes results in uncertainty (II). Given high levels of specificity and uncertainty (II), governance structures with higher-powered control, such as the government-led mode, are required to implement rural renewal and reduce transaction costs. However, because of the hierarchical mode, the actor leading the entire process of rural renewal, such as the local government, obtains the distribution advantages and the rural-urban social wealth gap is not significantly narrowed. Moreover, hierarchy may induce process efficiency losses. The rural renewal in S Village showed that the self-organized mode was also able to weaken the incentives for opportunistic behavior and strengthen the action control, thereby fitting the specificity and uncertainty (II) of the transaction and indicating that hierarchy was not the sole option.

Second, large scale of rural renewal leads to high level of complexity, while human being's cognitive limitations cause uncertainty (I). Given high levels of complexity and uncertainty (I) demand governance structures with decentralized features, such as the self-organized mode, to implement rural renewal in manner that reduces transaction costs. The indispensable preconditions for the supply of self-organization are the small scale of the actors, the large extent of voluntariness and interest homogeneity and abundant social capital. In addition, self-organization can effectively narrow the rural-urban social wealth gap.

Based on our research conclusions above, the policy recommendations are as follows. First, a "one-size-fits-all" mode for governing rural renewal is not available. The governance structure of rural renewal should be aligned with context-specific conditions, which are properties of the transactions and characteristics of the actors. Second, in terms of government-led rural renewal, introducing public participation and negotiation should be attempted because the mechanisms can fully exploit the dispersed local knowledge to ensure that the physical outcomes of rural renewal better meet the local demands and guarantee a more reasonable interest distribution. Third, farmers and villages with appropriate conditions should be encouraged to conduct rural renewal in a self-organized way and identify development paths that are suitable for local conditions, with the goal of gradually changing the method of social wealth transfer and providing a reliable and sustainable basis for rural-urban integration.

Admittedly, the empirical evidence from the two cases may be not sufficient to fully illuminate the governance fit and the performance difference of rural renewal. Moreover, we have not further clarified the ecological, external and interconnected outcomes of rural renewal, and have not yet investigated the impacts of landscape factor [20,45]. However, the research provides a number of insights: first, it provided abundant information on rural renewal in contemporary China and could be used as the basis for further studies; second, it combined the IoS framework with Williamson's TCE paradigm, thereby extending the extant research pattern while also providing new theoretical insights for understanding rural renewal; and third, it comprehensively explored the factors affecting governance fit and revealed the effects of the governance structure on the process efficiency and physical and distributional outcomes. All the aforementioned achievements may fill the research gap of relevant topics to some degree. Furthermore, subsequent research can be devoted to the determinants of rural renewal mode selection to provide more empirical evidence on the logic of governance fit. In addition, researchers can focus on both the direct and indirect (or hidden) performance of rural renewal from a broader perspective and propose more comprehensive recommendations for governance innovation.

Acknowledgments: This research has received financial support from the Natural Science Foundation of China through project No. 71573231, the Social Science Foundation of China through project No. 16ZDA020, No. 1425-03, No. 13AZD012 and No. 14ZDA039, and the China Scholarship Council through project No. 201706320201. The authors would like to thank the funding organizations for the grants.

Author Contributions: These authors contributed equally to this work.

Conflicts of Interest: The authors declare no conflict of interest. 


\section{References}

1. Fang, B.; Wu, C.; Yang, L. The case study of rural residential area consolidation and discussion on its development path. J. Anhui Agric. Sci. 2007, 35, 799-800. (In Chinese)

2. Chen, X. Agriculture and rural development: Current situation and problems. J. Nanjing Agric. Univ. 2013, 13, 1-10. (In Chinese)

3. The 16th CCCPC. The Bulletin of the 5th Plenary Session of the 16th CCCPC. 2005. Available online: http:/ / cpc.people.com.cn/GB/64162/134580/141447/ (accessed on 8 January 2018). (In Chinese)

4. The 17th CCCPC. The Bulletin of the 17th National Congress of the Communist Party of China. 2007. Available online: http:/ / news.xinhuanet.com/newscenter/2007-10/24/content_6938568.htm (accessed on 8 January 2018). (In Chinese)

5. The 18th CCCPC. The Bulletin of the 18th National Congress of the Communist Party of China. 2012. Available online: http://news.china.com.cn/politics/2012-11/20/content_27165856.htm (accessed on 8 January 2018). (In Chinese)

6. The 18th CCCPC. Decision of the CССPC on Some Major Issues Concerning Comprehensively Deepening the Reform. 2013. Available online: http://news.xinhuanet.com/politics/2013-11/15/c_118164235.htm (accessed on 8 January 2018). (In Chinese)

7. The 19th CССРC. The Bulletin of the 19th National Congress of the Communist Party of China. 2017. Available online: http:/ / www.xinhuanet.com/politics/19cpcnc/2017-10/27/c_1121867529.htm (accessed on 25 January 2018). (In Chinese)

8. Lotto, R.D.; Cattaneo, T.; Giorgi, E.; Venco, E.M. Coherences and Differences among EU, US and PRC Approaches for Rural Urban Development: Interscalar and Interdisciplinary Analysis. Sustainability 2017, 9, 537. [CrossRef]

9. Hao, P.; Sliuzas, R.; Geertman, S. The development and redevelopment of urban villages in Shenzhen. Habitat Int. 2011, 35, 214-224. [CrossRef]

10. Long, H.; Li, Y.; Liu, Y.; Woods, M.; Zou, J. Accelerated restructuring in rural China fueled by "increasing vs. Decreasing balance" land-use policy for dealing with hollowed villages. Land Use Policy 2012, 29, 11-22. [CrossRef]

11. Wang, Q.; Zhang, M.; Cheong, K.C. Stakeholder perspectives of China's land consolidation program: A case study of Dongnan Village, Shandong Province. Habitat Int. 2014, 43, 172-180. [CrossRef]

12. Jiang, S.; Liu, S. Capitalization of land and rural industrialization-A case study of Nanhai city. China Econ. Q. 2004, 4, 211-228. (In Chinese)

13. Chen, A.; Gao, J. Urbanization in China and the coordinated development model-The case of Chengdu. Soc. Sci. J. 2011, 48, 500-513. [CrossRef]

14. Li, L.H.; Lin, J.; Li, X.; Wu, F. Redevelopment of urban village in China-A step towards an effective urban policy? A case study of Liede Village in Guangzhou. Habitat Int. 2014, 43, 299-308. [CrossRef]

15. Hin, L.L.; Xin, L. Redevelopment of urban villages in Shenzhen, China-An analysis of power relations and urban coalitions. Habitat Int. 2011, 35, 426-434. [CrossRef]

16. Zhou, Z. Towards collaborative approach? Investigating the regeneration of urban village in Guangzhou, China. Habitat Int. 2014, 44, 297-305. [CrossRef]

17. Lin, Y.; de Meulder, B.; Wang, S. Understanding the "village in the city" in Guangzhou. Urban Stud. 2011, 48, 3583-3598. [CrossRef]

18. Wu, F.; Zhang, F.; Webster, C. Informality and the development and demolition of urban villages in the Chinese peri-urban area. Urban Stud. 2013, 50, 1919-1934. [CrossRef]

19. Li, Y.; Liu, Y.; Long, H.; Cui, W. Community-based rural residential land consolidation and allocation can help to revitalize hollowed villages in traditional agricultural areas of China: Evidence from Dancheng County, Henan Province. Land Use Policy 2014, 39, 188-198. [CrossRef]

20. Long, H. Land consolidation: An indispensable way of spatial restructuring in rural China. J. Geogr. Sci. 2014, 24, 211-225. [CrossRef]

21. Wang, Y.; Guo, X.; Liu, H. Synthetic evaluation of new socialist countryside construction at county level in China. China Agric. Econ. Rev. 2011, 3, 383-401. [CrossRef]

22. Hagedorn, K. Particular requirements for institutional analysis in nature-related sectors. Eur. Rev. Agric. Econ. 2008, 35, 357-384. [CrossRef] 
23. Thiel, A.; Schleyer, C.; Hinkel, J.; Schlüter, M.; Hagedorn, K.; Bisaro, S.; Bobojonov, I.; Hamidov, A. Transferring williamson's discriminating alignment to the analysis of environmental governance of social-ecological interdependence. Ecol. Econ. 2016, 128, 159-168. [CrossRef]

24. Williamson, O.E. The Economic Institutions of Capitalism; The Free Press: New York, NY, USA, 1985.

25. Hagedorn, K.; Arzt, K.; Peters, U. Institutional arrangements for environmental co-operatives: A conceptual framework. In Environmental Co-Operation and Institutional Change: Theories and Policies for European Agriculture; Hagedorn, K., Ed.; Edward Elgar: Cheltenham, UK, 2002.

26. Hagedorn, K. Can the concept of integrative and segregative institutions contribute to the framing of institutions of sustainability? Sustainability 2015, 7, 584-611. [CrossRef]

27. Ostrom, E. Understanding Institutional Diversity; Princeton University Press: Princeton, NJ, USA, 2005.

28. Ostrom, E. A general framework for analyzing sustainability of social-ecological systems. Science 2009, 325, 419-422. [CrossRef] [PubMed]

29. Williamson, O.E. Comparative economic organization: The analysis of discrete structural alternatives. Adm. Sci. Q. 1991, 36, 269-296. [CrossRef]

30. Williamson, O.E. The new institutional economics: Taking stock, looking ahead. J. Econ. Lit. 2000, 38, 595-613. [CrossRef]

31. Alexander, E.R. A transaction-cost theory of land use planning and development control: Toward the institutional analysis of public planning. Town Plan. Rev. 2001, 72, 45-75. [CrossRef]

32. Olson, M. The Logic of Collective Action: Public Goods and the Theory of Groups; Harvard University Press: Cambridge, MA, USA, 1965.

33. Ostrom, E. Beyond markets and states: Polycentric governance of complex economic systems. Am. Econ. Rev. 2010, 100, 641-672. [CrossRef]

34. Buitelaar, E. A transaction-cost analysis of the land development process. Urban Stud. 2004, 41, $2539-2553$. [CrossRef]

35. Furubotn, E.G.; Richter, R. Institutions and Economic Theory: The Contribution of the New Institutional Economics; University of Michigan Press: Ann Arbor, MI, USA, 2005.

36. Ménard, C. The economics of hybrid organizations. J. Inst. Theor. Econ. 2004, 160, 345-376. [CrossRef]

37. Hayek, F.A. The use of knowledge in society. Am. Econ. Rev. 1945, 35, 519-530.

38. Gerring, J. Case Study Research: Principles and Practices; Cambridge University Press: New York, NY, USA, 2007.

39. Vatn, A. Institutions and the Environment; Edward Elgar Publishing Limited: Northampton, UK, 2005.

40. Tan, R.; Beckmann, V. Diversity of practical quota systems for farmland preservation: A multi-country comparison and analysis. Environ. Plan. C Gov. Policy 2010, 28, 211-224. [CrossRef]

41. Tan, R.; Wang, R.; Sedlin, T. Land-development offset policies in the quest for sustainability: What can China learn from Germany? Sustainability 2014, 6, 3400-3430. [CrossRef]

42. Ostrom, E. Governing the Commons-The Evolution of Institutions for Collective Action; Cambridge University Press: Cambridge, UK, 1990.

43. $\mathrm{Xu}, \mathrm{Y}$. Reinstating autonomy: An exploration into the effective forms for realizing villager autonomy. J. Chin. Gov. 2016, 1, 157-173. [CrossRef]

44. Zhang, L.; Wang, S.X.; Yu, L. Is social capital eroded by the state-led urbanization in China? A case study on indigenous villagers in the urban fringe of Beijing. China Econ. Rev. 2015, 35, 232-246. [CrossRef]

45. Gu, X.; Dai, B.; Chen, B. Landscape effects of land consolidation projects in Central China-A case study of Tianmen City, Hubei Province. Chin. Geogr. Sci. 2008, 18, 41-46. [CrossRef]

(C) 2018 by the authors. Licensee MDPI, Basel, Switzerland. This article is an open access article distributed under the terms and conditions of the Creative Commons Attribution (CC BY) license (http://creativecommons.org/licenses/by/4.0/). 